\title{
Memories of Early Cedar Rapids
}

\author{
By John S. ELY
}

The author of the article, John Stoney Ely, was born November 18, 1853 , at Cedar Rapids, Iowa, where he later became a successful businessman with large real estate holdings in that city. He passed away February 18, 1950, at the venerable old age of 96 . His grandson, John M. Ely Jr., who gave the ANNaLs permission to print these memoires, is presently serving his first term in the Iowa legislature as a representative from Lynn County.

I have had the very exceptional experience of living in one town for my entire lifetime of more than ninety-five years, from the horse and buggy and tallow candle days to these modern times of the airplane and the electric light-a development unparalleled in all the world's history.

The house where I was born occupied a site in the center of the block on Second Avenue between Second and Third Streets. It was situated on the mound about ten or twelve feet above what is the present street level. At that time none of the streets in Cedar Rapids were graded. Indeed, it was not until 1865 that the grading of the street necessitated the building of a stone retaining wall extending from Second Street to Third Street and along Third Street to the alley, a four foot stone wall with a six inch coping, quite a marked improvement at the time. This home was the first lath and plastered house, and at the time of my birth the most pretentious home in Cedar Rapids. The family occupied it until the fall of 1868 , when we moved to a house directly across the street on Second Avenue. This home being so near the center of the town and so prominent caused my early life to be spent in the center of the town's activities and I was, therefore, in personal contact with events as they occurred.

At the time of my birth in 1853 , the population of the village was about four hundred. The community was growing rapidly and at the time of its incorporation into a town in 1856 there were probably a thousand people here. At the time of our removal to the home across the street in 1868 the population was about four thousand. In 1853 the business section of Cedar Rapids was confined to a small section on North First Street, adjoining the mills at the dam of the Cedar River. 
As the town grew it extended down First Street to Third Avenue, and to some limited extent up First and Second Avenues by 1866 .

I might record here that I make use of the present naming of the streets rather than the old. What is now First Street was Commercial Street; Second Street, Washington; Third Street, Adams; Fourth Street, Jefferson; "B" Avenue was Benton; "A" Avenue was Linn; First Avenue was Iowa Avenue (a name which I have always maintained should have been retained, it being quite distinctively the main thoroughfare of the city); Second Avenue was Eagle; and Third Avenue was Park Avenue.

Our house was erected in 1846 or 1847. It was of quite large size for that time and the interior on the first floor was arranged with a parlor, dining room, two bedrooms and a kitchen with pantries and closets. In the upper story, or half story, there were four small bedrooms, each barely admitting a bed, wash-stand, and bureau. Downstairs there was the kitchen stove, an open front Franklin stove in the parlor, a sheet iron stove in each of the two bedrooms, and in the dining room a sheet iron stove with a stovepipe running into one of the bedrooms above the dining room, that being the only bedroom heated in the upstairs. I mention these stoves because they played such a large part in my younger activities when wood had to be furnished as it was the only fuel used in those days. Besides the ordinary furniture in the several rooms there was a large Chickering piano in the parlor, and a large double mahogany bed in one of the bedrooms. This bed was raised up high enough for a trundle bed to be rolled under the foot where I as a baby slept safely stored away with only my head exposed.

There was also in one of the bedrooms a Tiger and Farr sewing machine, the first sewing machine ever brought to Cedar Rapids, and the only one in town in 1861 when the Civil War broke out. It was on this machine that the flag was made which was presented to the first company of soldiers which left for the front in '61, and it was in very constant use in the making of clothing and bandages for the soldiers at the war front. 
On the floors there were rag carpets or rugs, supplanted by matting, which was used in the summer time. Of course, there were no wash rooms or toilet conveniences, and the lighting was done with candles and fluid lamps. The fluid lamps burned an oil which was very inflammable, and they accomplished this by means of a couple of small tubes on top through which the wick was drawn and they were used without a chimney. I remember that I was never allowed to carry one of these lamps and could only use candles, which were homemade. These fluid lamps were later supplanted by kerosene lamps with glass chimneys, which were used until gas was introduced. The public gas and water systems were at that time unknown and not available until some time after the Civil War.

On the outside, the approach to the house was up a flight of steps, the house being located approximately twenty feet from the lot line. The barn was on the alley about forty feet from the rear of the house, with a cow shed on the west side. The privy and pig pen were on the east side of the barn and adjoining them was the $\mathrm{V}$-shaped vat where the ashes were stored. I had my share in the work of leaching these ashes in the vat to get the lye for making the soap. This we did in a large iron soap kettle provided for the purpose. Adjoining the leaching vat was the ice house, wholly below the surface of the ground with only the roof showing. In it were stored the blocks of ice hauled from the river and covered with sawdust for use in the summer. There were a number of ice houses in the village, but I recall that ours was in great demand and its use was quite generously shared with neighbors. Ice was considered a great luxury, there being no public ice house. I also recall breaking up large chunks of ice which were hauled up from the river in the winter time to melt in the copper boiler on the stove to get soft water for the family washing when there was no water to be had in the cistern.

The rest of the ground on the east side of the house was used as a garden, it being a great ambition of my father to raise vegetables, fruits and flowers, a very difficult thing to do on a sand hill such as this was. On the west side of the house 
the hill sloped down to Second Street, there being several honey locust trees next to the house, planted for shade.

My grandfather, John Weare, Sr., who was a justice of the peace in Cedar Rapids, came to live with us in 1851 or 1852. He occupied the bedroom on the west side of the house, which was also his court room, and in the summer time he held court under those locust trees, dispensing justice perhaps not always with legal decisions but with good common sense. This outside court was attended by a large number of the citizens.

In the angle formed by the bedrooms and the main home on the east side was the cistern, a very large one covered with a platform and with a grape arbor over it. In the center was quite a unique pump, being a chain with disks coming up in a pipe and running over a sheave pulley which was turned by hand. This was a very reliable pump because it never froze up in the winter time. I well remember pumping cistern water with this pump for the Saturday night baths into one of the family wash tubs. These Saturday evening baths were a fixed and regular performance whenever the weather would permit. The well adjoined the cistern on the side of the house and was approximately twenty-five feet deep, curbed with stone and the water raised by a rope running over a pulley hung from the roof of the wooden canopy which covered the well. At one end of the rope was the bucket and at the other end a wooden block used as an offsetting weight in hoisting the bucket of water. This well was in great use as water had to be obtained from it not only for household uses but for watering the garden during the dry summers.

Owing to its size and central location and to the fact that the hotel accommodations of the town were limited and very poor, our home for many years was used for the entertainment of not only relatives and friends but of the prominent people coming to Cedar Rapids for various purposes. Cedar Rapids was quite distinctively cultural in the character of its early settlers, fostering literary societies, lyceums, and educational forums. These brought prominent lecturers to our town, while the developing railroads brought prominent financial 
personages. The lectures were held in the Baptist Church, diagonally across the corner from our home. I recall the famous publisher, Wendell Phillips, who lectured on "The Lost Arts"; John B. Gaugh, the noted temperance lecturer, whose subject was "Habits"; Bayard Taylor, the noted traveler and explorer, who lectured on "Words We Use"; Elihu Burritt, the learned blacksmith; and William Lloyd Garrison, who along with Wendell Phillips was a distinctive welcome guest, they both being prominent abolitionists in those days. My mother and father were radical abolitionists before the Civil War; indeed, the family home in Allegan, Michigan, prior to their coming to Cedar Rapids, was a station on the underground railroad where the fugitive slaves from the Southern. States could come and be passed on to freedom in Canada. Besides these there were prominent business and financial men, among whom was Oakes Ames, of unsavory reputation in connection with the Credit Mobilier governmental scandals of a later date; and John I. Blair, a very prominent factor in the railroad development of this section. My recollection of the former is quite distinct because he gave me a five dollar gold piece with which I bought a new pair of skates with the front runners curved up over the feet in a large spiral.

The town calaboose was located on the rear of the lot at the corner of Third Avenue and First Street-a wooden building about 12 to 15 feet square with one grated barred window. This was always an object of interest and curiosity as well as of dread to me when a small boy. Troubled as I was with a more or less guilty conscience-I avoided going near itand the town marshal, who had charge of it, was an ogre to the small boy.

Opposite, on a vacant lot, was the town pound for stray animals, kept for redemption when claimed by the owners.

When about ten years old, my father, to encourage thrift and responsibility, gave me two little pigs, to be cared for, and to be wholly my own, and when grown-up and sold, I was to be a rich capitalist. They were Chester White pigsof the finest breeding, and as such, they had the best of care and attention by me, and the pen, situated on the alley back of the house, was kept in immaculate order. Unfortunately, 
the town authorities finding that stray animals, especially hogs, were becoming a public nuisance, offered a reward to anyone bringing such strayed animals to the pound. The immediate result was that boys all about town were making night raids on pig pens, opening them up and taking the pigs to the pound, where they claimed their reward.

Of course, living in the heart of the town, I was one of the first victims, and within a day or so, my pigs were among dozens of others in the pound, hopelessly mixed, and I had to be content with redeeming my choice Chester Whites with a pair of mongrel bred specimens. The order was quickly repealed by the authorities and the whole matter considered a huge joke by almost everyone but me.

As a boy it was one of my jobs to help in getting the wood piled away in the shed for use in the winter, to be followed by filling the woodboxes for each stove in the house. This was no small undertaking when it is considered that we often had severe winter weather and I have recorded that on the days of January 7,8 , and 10 in 1856 the temperature was 25 to 30 degrees below; and on January 20, 1857, it was 38 below zero. It might be well in this connection to mention more fully about the wood supply, which being the only fuel used in those days formed such an important part in life in the western prairie country. The timber growths were confined along the wooded sections of the rivers and streams and some few groves of native timber scattered over the prairie. These timber lands were of such value that they were among the first to be acquired by the early settlers and until the use of coal they were of greater value than the prairie country.

Every now and then pigs were killed for meat. It took about double the time for them to mature than it takes in these modern days. They were never slaughtered on the premises but their carcasses were delivered to our home for cutting up into the various cuts of pork and were stored away for consumption.

In the summer time my duties were largely taken up with the garden, watering the plants, weeding out the flower beds, hoeing the vegetables, and particularly do I remember keeping the potato patch free of potato bugs, which had to be 
picked off by hand as we had no sprays for pests that I can recall.

Indoors, besides keeping the woodboxes filled and the fires built, I had to trim the lamps and keep them filled and had a hand in making tallow candles, which were necessary in our home life.

Illustrative of the petty economies exercised in those days, we used candle and lamp lighters and in each room in a small receptacle these were kept. These lighters were merely a strip of paper coiled up in spiral form and bent over at the ends to hold the spiral. Owing to the scarcity of matches these were in general use, lighting them from the stove and so to the lamps and candles. In addition to these lamp lighters there was a tray holding snuffers and extinguishers to put out the candles, which were never allowed to burn longer than necessary.

Boyhood sports are more or less hereditary from generation to generation, changing only with the seasons. Of course, there were coasting and skating in the winter. There were two welldefined coasting hills in town, the smaller one on the corner of Sixth Street and Third Avenue where the Peoples Church is located, and the big hill on " $\mathrm{A}$ " Avenue where is now the viaduct. This latter hill was considered somewhat dangerous, especially for small boys, for although there were no railroad tracks to cross, it was very steep and covered with the stumps of trees. Skating in the winter was always a favorite sport, starting in the early season on the many ponds around town, then on the slough, and later on the river when it was frozen over. The latter was very treacherous and hazardous, taking its toll every winter among the skaters for the new ice was the smoothest and appealed to the venturesome. A valuable contribution of the river to the welfare of the community in the winter season was the use of its frozen surface to bring the necessary wood for winter fuel and for ice for summer use. For a number of years, trolling races were held on a course on the ice above the dam.

I must mention a favorite winter sport of the boys of those times; catching on bobsleds when sleighing was good, often riding up the river or out in the country with a chance of 
catching a ride back to town, or walking if no return sled came along. On Saturdays there were crowds of boys around town doing this, and woe betide the farmer with an empty bob who refused a ride, for he would be pelted with snowballs and be a marked man thereafter.

Then there were the time honored sleigh rides, fifteen or twenty boys and girls bundled in the straw-filled bobsleds with plenty of buffalo robes for a ride to Marion on a moonlight night, or to some farm house for a square dance or a taffy pull.

I remember how popular my Uncle Lowell Daniels was, who had a famed sorrel team with a fine cutter, nearly always loaded down with a cargo of boys. I tried in every way to cultivate his good will and was amply rewarded by frequent invitations for sleigh rides. In the late summer or early fall I would drive with him when he went out prairie chicken hunting or after ducks, for he was a famous hunter. My province was to hold the horses while he hunted and to mark down the game when shot. When I was a boy, prairie chickens were in great abundance and were found within a short drive to the unbroken prairie west of the town, while ducks were plentiful on the slough and bayous up and down the river.

All the boys wore boots in the winter time, with copper tips and well-greased to be water proof. Boots were in general use by men also, and every room was furnished with a bootjack with which to pull them off. In summer boys very generally went barefoot in spite of the sandburs which were universal on the sandy soil of the town.

There was the river for swimming, boating and fishing. The old swimming hole was on a sandbar at the lower end of the island and, there being no bridge, was to be reached only by wading when the river was low, or by boat when the water was high. The island was thickly covered with cottonwood trees and driftwood and was a great resort for boys both summer and winter. There was at that time, and still exists, a large black boulder in the middle of the river two or three hunderd yards below the dam which was the gauge for measuring the depth of the water. When the water reached the top of this stone, the river could not be forded and the 
swimming hole was abandoned for the time being. Later on when the Northwestern Railroad bridge was built just after the Civil War, the swimming hole was transferred to the west end of that bridge. This move was caused by fastidious people objecting to naked boys in such public view. Of course no girls knew how to swim in those days.

The Cedar River in the pioneer days was noted among the Iowa streams for its fish, largely due probably to the numerous rapids with their rocky bottoms and the wooded bluffs which lined its course. I remember the fish market at the foot of First Avenue kept by a man named Fox and supplied with all kinds of river fish caught by traut (trot) lines and by seining with a long seine or with large dip nets rigged up on the dam; such methods long ago outlawed. Some of the fish now seem to be extinct in the Cedar River, for I remember besides the large catfish that sturgeon and gar pike were also caught. I recall being with my father when he caught a twenty-four pound pike at the mouth of Prairie Creek.

Many of the games of my boyhood days are still in use: such as, Hide and Go Seek, Prisoners Base, Fox and Geese, Pull Away, Hop Scotch, Duck on the Rock, Shinny, Marbles, and Jack Stones; all recognized with variations today. Of course, there were ball games of great variety, although present day baseball had not been evolved. Croquet was introduced about the beginning of the Civil War and was very popular; my father having what was the first croquet ground in town.

Closely associated with the sports of boyhood days were the shows, circuses and entertainments. Prior to the Civil War each summer brought several circuses to Cedar Rapids and these were memorable occasions for the small boy. They usually came via Iowa City and were greeted by crowds of boys who often ventured several miles out in the country to welcome and follow them into town. The first one I recall was Yankee Robinson's, who was the P. T. Barnum of his day. Prior to the circus and for a long time after each one, we small boys were imitating the performers and the clowns with amateur shows in tents and barns with pins for admission fees. Then there were the traveling troupes of entertain- 
ers, acting in front of their large painted panoramas depicting "Paradise Lost" and Biblical scenes. But especially do I remember the Swiss Peek family, bell ringers, with their yearly visit, for Willie Peek, ringing the small bells, was my boy ideal when dressed in Swiss costume he sang.

"So let the wide world wag as she will, I'll be gay and happy still."

Also, my memory is flooded with recollections of the many home parties of girls and boys when we played Blind Man's Buff, Pussy in the Corner, and the various kissing games in vogue in those days.

In those days John P. Wolf, who constructed the Chicago and Northwestern Railway when it came to Cedar Rapids, lived on Oak Hill. Mr. Wolf was a great lover of horses and having large means, he devoted his attention to their development. He built a half-mile racing course where the packing house is now located, with extensive barns and training quarters, making it not only an indulgence of his favorite sport, but a business venture of great importance. Especially notable was his development of the Hamiltonian breed (standardbred) of horses well-known throughout the entire country. One of his horses was "Tom Heyer" who held the trotting record of the entire country for several years. All of this gave our town a great prominence as a sporting center, attracted many lovers of the sport and breeders of horses to our small community.

As the town was originally founded because of the rapids of the Cedar River, at this point I will now make mention at some length of some facts regarding the river.

I can readily recall my mother's enthusiastic account of the first time she saw the Cedar River. It was in 1842 when on a visit to Iowa to see her sister living near Marion, she rode on horseback for the five miles to see the rapids of the Cedar River. Coming to the brow of the bluff overlooking the valley, she looked down upon the beautiful scene before her and was captivated by the sight. On returning to her home in Allegan, Michigan, she gave such a glowing account of it to her husband that two years later when she came a second time, he accompanied her. Being an experienced miller, he readily 
recognized the value of the water power for development and as a result of this visit, Alexander L. Ely came in 1845 to make his home in Cedar Rapids. He obtained an interest in the town site and erected the first permanent dam and flouring mill on the Cedar River.

The Cedar River, an aggregation of many smaller streams, seemed to provide ideal conditions for the settlement and development of the country through which it ran, and it was the main artery of commerce in the pioneer days and entered into every phase of life, social as well as industrial.

On the early maps it was designated as a navigable stream and when Cedar Rapids was first platted, the steamboat levee was a prominent feature. I can recall going down to the levee to watch the landing of the steamboats making regular trips to St. Louis to welcome my father among the passengers arriving from that city on the steamer, "Cedar Rapids." My father was one of the principal owners of this great boat which made its first trip from St. Louis in 1858 and after two seasons was destroyed in a collision on the Mississippi River. This was considerable of a boat, being one hundred fifty feet long and twenty-six feet wide, and carried two hundred fifty tons, 32 passengers and a crew of 6 men on its maiden trip down the river. I remember it quite well for its arrival and departure were great events in the life of the town, most of the population flocking to the levee at the foot of First Avenue to geet its arrival and see it depart. It now seems inconceivable that a boat of that size could successfully navigate the Cedar River, and it must lead to the conclusion that there was far more water in the river than in these times. It is also to be mentioned that at this period the steamers, "Valley Queen" and "Black Hawk," coming from the Mississippi River to Cedar Rapids were hauled around the dam to make regular trips to Waterloo which were continued for several years. A neighbor of ours, J. J. Snouffer, was the captain of one of these boats, and on one of its trips Frank Boyce and I, being about twelve and thirteen years old, asked the captain if we could go with him. He readily gave his consent, but asked as a consideration that we pump the water out of the boat as it leaked a little. There was only a few inches of water in the 
bottom at the start and this seemed to be a very small job, but when the boat got underway with its tow, it sank deeper in the river and new leaks developed. So, from the start to the finish, Frank and I earned our passage with the hardest job in our young lifetime.

My cousin, Elisha D. Ely, was one of the builders of the first bridge erected across the Cedar River which was located near Seventh Avenue where the river was narrowest. The piers were cribs of plank resting on the river bed and though filled with rock were very largely held in place by the weight of the super structure. The bridge served its purpose at the ordinary stage of the water flow, but was wholly inadequate at its flood stages. By the time of the spring flood of 1858 , though it had been in use for only about six months, it was condemned and at the day of its final collapse most of the inhabitants of the town were there to witness it.

Following the usual trend of emigration westward from the eastern states along the same latitude, the first settlers in our city were largely of New England ancestry and brought with them the pronounced traits of the inhabitants of that section, intensity of purpose, thrift, devotion to family, and strict in their moral and religious observances. Also, they believed that education and public charitable institutions were fundamental to the government of a free people, therefore, it followed that these traits were implanted in our city at its very infancy, and to a very marked degree influenced its growth and prosperity.

When the original proprietors of the platted townsite decided to divide up their joint ownership, it was agreed that the two parks would be set aside for public use and that there should aiso be reserved three sites for churches. One was on the corner of Third Avenue and Fourth Street which was occupied by the first brick Methodist church, a small structure about $25 \times 30$ feet in size and where the Union Depot now stands. Another was on the corner of Second Avenue and Third Street, occupied by the so-called Little Muddy Church, the first church building in Cedar Rapids; and the third on the corner of "A" Avenue and Seventh Street is now occupied by Grace Episcopal Church. 
I have in my possession two small memorandum books in my father's handwriting and containing the lists of the lots in the town site with the prices established for each lot and to whom they were allotted. This appraisal was made in 1847 by the court commissioners appointed in a friendly suit to make the division of the property among the several joint owners. The most valuable lot of the original appraisement was the northeast corner of Commercial Street and Linn Streets, now First Street and "A" Avenue, which was priced at $\$ 75.00$, $\$ 1.25$ per front foot. The lot on the corner of Second Avenue and Second Street where the Dows Building is located was then appraised at $\$ 15.00$ or $\$ .30$ per front foot on Second Avenue. These same lots as shown by the assessment for 1947 were valued at $\$ 250$ and $\$ 2,000$ respectively.

In 1853 there arrived in Cedar Rapids a colony of six or seven families from South Carolina-Bryan, Legare, McIntosh, Rutledge, and Stoney. These people were of the most prominent families of that state, refined, educated, and cultured to a remarkable degree. Strange as it may seem, although they were all slave owners, they sold their slaves and emigrated because of their anti-slavery beliefs. I never knew just why they chose Cedar Rapids but I have always thought that my mother had something to do with it as she was the devoted friend of the Stoney family, so much so that I was named after one of them, John Stoney.

Their venture proved to be an unfortunate one and they all returned to South Carolina before the outbreak of the Civil War as they could not endure the northern climate. Their fate was a tragic one for they returned home to live almost in poverty and to endure the baleful days of the Reconstruction Period. The sale of their Cedar Rapids property in the following few years served to save them from almost entire destitution.

I will mention one instance which will illustrate the importance of these people in their native state. Mr. Theodore Stoney, brother of the E. J. Stoney who came to Cedar Rapids, was the owner of the largest plantation in South Carolina, if not in the entire southern states. He owned the Revecca Plantation with more than four hundred slaves and had the 
distinction at the outbreak of the war of being on the staff of General Beauregard, the Confederate commander, and in that capacity was one of the first to fire upon Fort Sumter.

In reviewing my school days in these earlier years I am somewhat surprised at the number of schools I attended, and in consequence the lack of any continuous system in my early education. I think this is to be accounted for by a succession of private schools, usually lasting but a year or two, and favored by my parents in order to assist some friend who was temporarily teaching for her livelihood. The first school that I can recall I attended was conducted by Miss Mary E. Graves, who was a relative of the Judge Greene family. A memorandum of my father shows that he paid two dollars and fifty cents for the term's tuition, not a very high valuation placed on the instruction I received. In the fall of 1862 I entered the public school, or as it was then called "the Free School."

The Free School occupied the site of the Washington High School building on Fourth Avenue between Fourth and Fifth Streets. The school was a two-story, brick building, with a high basement which was used for storing wood for winter use, and with the upper two stories used for school rooms. At the time of its creation about 1858, it was considered one of the finest school buildings in the State. The principal in 1859 was Professor P. Humphrey and the attendance at that time was the large number of two hundred and twenty-five scholars. Mr. Olmsted, one of the teachers, had an interesting method of teaching us the pronunciation of the vowels in the alphabet. We would be all arranged in line and recite in unison the different vowels with their phonetic sounds. This we did shouting at the top of our voices. I can recall McGuffey's Readers from the very first and the McGuffey's Speaker from which we had our selections to declaim on the platform every Friday afternoon. In recitation each class was arranged in a standing line with toes along a crack of the floor to maintain the alignment. Quite often in recitation such as spelling and mental arithmetic there were promotions in the line as one question would be missed and the next person in line if giving the correct answer was promoted. If by continual promotions in the line he or she reached the head, it was supposed to be a coveted position in the school. 
In 1864 a private school was opened up in the crypt of Grace Church by Miss Winchester, assisted by Jennie Carpenter, who was a niece of my uncle, Dr. S. D. Carpenter. I attended this school for a year and in the fall of '65 was privately tutored at the home of my Uncle John Weare by Miss Sarah Rogers, who the next year with her sister, Sophia, opened up a school called the Oak Hill Seminary, which was located on an oak tree covered knoll on First Avenue opposite the present Masonic Library. This school flourished for only one year and was succeeded by Parsons Seminary in 1867, which I attended. Parsons Seminary was one of the predecessors of Coe College, and was opened up in the Woodsworth Block on Second Street between Fifth and Sixth Avenues and was located there for one year pending the construction of what is now the main building of Coe College.

The Civil War had a very marked effect on the life of a small boy and in no respect was it more evidenced than in the change in his sports and pastimes, all of them taking on the martial character; the fife and drum, little leaden soldiers, wooden swords and guns, became the toys of the small boy. When the several battles were fought, they were re-enacted with snow forts, attacks with snowballs, corn cobs, and cranberries as ammunition. Even the bitter rancors and antagonisms of war times reached down into the life of the boy, and while fighting had always been more or less incident to the life in a small town, yet in those days it was very greatly accentuated and fist fights were much in evidence whenever a crowd of boys gathered together.

Cedar Rapids was overwhelmingly loyal during the war and very largely represented in the Union Army, and so I remember how we celebrated each victory with bonfires and shooting off anvils in place of cannon. My especial contribution on these occasions was to ring the bell of the church which was across the street from our home. It was the only large bell in town and was in frequent use not merely for church purposes but for public use in the town life.

I can properly note here that on the night when the news came that the Armistice was signed closing World War I, I rang the Presbyterian Church bell to the same intent and 
with the same zest as I had done fifty-three years previously when celebrating the surrender at Appomattox which terminated the Civil War.

Well do I recall when Company D of the First Iowa Regiment after drilling for a short time on the school playground, left for the front on the ninth of May 1861. The railway depot was then down at the lower end of town near Twelfth Avenue, and almost the entire population gathered to see the soldiers leave. When Lee surrendered, there was a great celebration which was to be followed shortly by the mourning for the beloved Lincoln. At this time war feeling and prejudices seemed to reach their climax, for the returning soldiers were bent on having vengeance on those, who staying home during the war, had in one way or another opposed the war or sympathized with the enemy. On one occasion I recall a crowd reaching mob violence which raided the book store of $E$. R. Derby and scattered his stock out in the muddy street because he had sold the Chicago Times during the war. They afterwards raided the store of Brown and Harper on First Street because it was rumored the latter had said he was glad Lincoln was shot. I vividly recall these scenes and experiences, the more so for my father was surgeon of the Twenty-fourth Iowa Regiment, which was recruited from Linn and adjoining counties. Frequent letters came from him to my mother with war news and interesting items of the welfare of the men, listing the dead and wounded not only of his own regiment but of the others recruited in this vicinity, making our home somewhat of a clearing house for war information while father was in the army.

After the war was over my father, whose health had been ruined during his service in the army, abandoned his profession and in 1866 became right-of-way agent for the Chicago and Northwestern Railroad, then building across the State. I was thirteen years old and accompanied him that summer, driving the team of horses while he was purchasing the land for the track and for town sites.

At the time of my earliest recollection there were three churches in Cedar Rapids, the Presbyterian, Methodist, and Episcopalian; and about these three organizations the whole 
life of the place centered. There was a very considerable representation of New England ancestry among the early settlers and this descent predominated in the Presbyterian Church. As my parents were among the original founders of this Church, very naturally I was brought up in its religious atmosphere. However, this faith and belief was coupled with a respect and tolerance for those who differed with them. The Presbyterian Church, known familiarly as "Little Muddy," was located on the corner of Second Avenue and Third Street, directly across the street from our home. It was erected in 1850 on a lot donated for the purpose by Addison Daniels, one of the founders of the town, and was called "Little Muddy" because it was constructed of grout (crushed stone and lime), placed in forms layer on layer. The population of the town was at that time about two hundred people and its erection was largely with labor and material contributed by everyone regardless of religious creed or sect. Its size was twenty-six by forty feet, but as I recall it from memory when I was four or five years old, it was an immense structure overpowering in its grandeur. About that time there was a belfry built in front to accommodate a bell of considerable size weighing three hundred and twenty-five pounds. Originally it was equipped with benches for seats, soon, however, to be replaced with pews of oak and walnut. The pulpit was walnut. "Little Muddy" served its good purpose until 1869, when the new church was completed, although it was used by the Sunday School for several years after that date. I was a very integral part of the Sunday School and to be absent from it of a Sunday was almost an unheard of event.

I can recall all the pastors of the Church in my boyhood days: Williston Jones, whom I knew later in life; his successors, Mr. Dudley, Mr. Atherton, and Mr. Knox. There were no D.D.'s at that time. They were saintly, consecrated men-pastors, ministers and preachers in the real definitions of the words. Then there were the itinerants who came frequently for preaching and other religious purposes, as devoted, selfsacrificing men as I have ever known, a class now long since passed away and forgotten, the pioneers in religion among the founders of the Western country. I recall Mr. Spees with his 
long, snow-white beard, a patriarch in appearance as well as in his labors; and Samuel Storrs Howe, who lives in my memory from the stories he told me of Indian experiences; and then there was good old Father Roberts who walked from Iowa City to Cedar Rapids and began his sermon on Sunday, the next day, "I come before you this morning, brethren and sisters, with an enfeebled body and a sluggish mind"-and then preached the customary two hours. These pastors and itinerants were always welcome guests in our home and a benediction always accompanied their presence.

And so I come to the end of my narrative which I have confined to those early years when I was free of personal responsibilities. It is a very pleasant pastime at my time of life to recall the days of my youth, much more so than to remember incidents of later life when mistakes and errors of judgment becloud the memory with regrets and disappointments.

\section{Library Notes}

The pseudo and the scientific are well represented in the recent acquisitions of the past few months by your Historical Library. The pseudo came to us in the form of a copy of Ayer's American Almanac for the Use of Farmers, Planters, Mechanics, Mariners and All Families 1869. It offers up such rare gems of wisdom as, "Less than one-half of the females in this country have sound health.... I believe this condition arises from two causes: one is the lurking contamination of constitutional scrofula and the other is the fact that the AngloSaxon race is not yet acclimated on this continent. Time will cure the last; and the first should be remedied by ... [Ayer's] Sarsaparilla."

The second and decidedly scientific acquistion is Space Research, the proceedings of the First International Space Science Symposium at Nice, Italy, January, 1960, which contains a paper presented by James Van Allen of the State University of Iowa on the "Origin and Nature of the Geomagnetically-trapped Radiation.” 
Copyright of Annals of Iowa is the property of State of Iowa, by \& through the State Historical Society of Iowa and its content may not be copied or emailed to multiple sites or posted to a listserv without the copyright holder's express written permission. However, users may print, download, or email articles for individual use. 